\title{
Konsep Dasar Pelayanan Anak Menurut Matius 19:13-15 Dan Implementasinya Terhadap Kualitas Pelayanan Guru Serta Pertumbuhan Rohani Anak Sekolah Minggu
}

\author{
Rini Sumanti Sapalakkai, ${ }^{1}$ Agiana Her Visnhu Ditakristi, ${ }^{2}$ Benteng Martua Mahuraja Purba ${ }^{3}$ \\ Prodi PAK, STT Real Batam \\ Prodi PAK, STT Real Batam \\ Prodi PAK, STT Real Batam \\ rinigenovita@gmail.com
}

\begin{abstract}
The purpose of this paper is to find out the basic concepts of children's services according to Matthew 19: 13-15 and their implementation of the quality of teacher services and the spiritual growth of Sunday school children in GBI house of glory batam. The type of research used is based on qualitative methods ie data collected by observation and book literature. Children's ministry is a duty and responsibility from God. This task is a noble work that God has given to His people who are called in the ministry of children. Being a child servant is not an easy thing to do. Children's ministry requires a serious and committed heart. The purpose of child ministry is to bring children to the knowledge of Jesus and accept Jesus as Lord and Savior and help them to have a good relationship with God so that they grow spiritually mature.
\end{abstract}

Keywords: Concepts, Children's Services, Quality, Spiritual Growth

\begin{abstract}
Abstrak
Tujuan penulisan ini adalah untuk mengetahui konsep dasar pelayanan anak menurut matius 19:1315 dan implementasinya terhadap kualitas pelayanan guru serta pertumbuhan rohanian anak sekolah minggu di GBI house of glory batam. Jenis penelitian yang digunakan yaitu berdasarkan metode kualitatif yakni data yang dikumpulkan dengan observasi dan literatur buku. Pelayanan anak adalah suatu tugas dan tanggung jawab dari Allah. Tugas ini merupakan suatu pekerjaan yang mulia yang dikaruniakan Allah kepada umat-Nya yang terpanggil dalam pelayanan anak. Menjadi seorang pelayan anak bukanlah hal mudah untuk dilakukan. Pelayanan anak membutuhkan hati yang serius dan berkomitmen. Tujuan pelayanan anak adalah membawa anak kepada pengenalan akan Yesus dan menerima Yesus sebagai Tuhan dan Juruselamat serta menolong mereka memiliki hubungan baik dengan Tuhan agar mereka bertumbuh dewasa secara Rohani.
\end{abstract}

Kata kunci: Konsep, Pelayanan Anak, Kualitas, Pertumbuhan Rohani Iman

\section{PENDAHULUAN}

Dunia anak-anak merupakan dunia yang rumit dipahami oleh orang dewasa, sekalipun semua orang dewasa pernah tingal di dalamnya. Salah satu penyebab kerumitan tersebut adalah perubahan total antara anak-anak dan orang dewasa. Perkembangan dunia dalam segala bidang semakin meningkat dari waktu ke waktu. Adalah sebuah fakta yang tidak dapat di pungkiri bahwa perkembangan dunia yang kian maju membawa perubahan demi perubahan dalam kehidupan manusia. Perubahan tidak dapat dihindari. Kalau sekitar dua puluh tahun yang lalu, masih mudah di jumpai anak-anak usia sekolah yang bermain 
outdor dengan permainan yang bertangkaskan fisik seperti : (lompat tali, bentengan, kasti dan lain-lain), tapi saat ini lebih muda dijumpai anak yang menyendiri ataupun berkelompok sambil main gadget. Pemandangan ini bukan hanya terjadi di dunia anak secara umum akan tetapi juga di dalam gereja atau dikenal dengan anak Sekolah Minggu.

Perubahan ini juga mempengaruhi keberadaan gereja Tuhan dalam melaksanakan tugas dan panggilannya untuk bersaksi, bersekutu dan melayani. Dalam hal ini gereja harus siap menghadapi segala tantangan yang ada dengan meningkatkan mutu pelayanan dan kehidupan jemaat. George Barna seorang tokoh pertumbuhan gereja megatakan mengatakan: Gereja itu berada ditengah-tengah lingkungan yang sedang bersaing. Gereja setempat sedang bersaing dengan organisasi-organisasi lain untuk merebut waktu, perhatian, uang, kesetiaan dan singkatnya menarik hati orang banyak. Gereja dapat melihat bagaimana pendekatan Yesus kepada setiap orang melewati batas-batas social pada saat itu. Hal ini secara unik dijelaskan oleh Fredy Simanjuntak, Yesus begitu terbuka dan dekat dengan orang berdosa. ${ }^{1}$ Di zaman Yesus memang dapat digambarkan bagaimana Yesus begitu proaktif berdekatan dengan semua orang dari yang tertua sampai kepada yang termuda. Tentunya Gereja juga harus terbuka dengan berbagai hal di zaman modern ini. Persaingan yang sesungguhnya bukanlah gereja lain melainkan oraganisasi, kesempatan dan filsafat lain yang dapat menjadi alternatif untuk kehidupan Kristen. Saingan utama itu datangnya dari siaran radio, film, tempat-tempat hiburan, klub-klub olahraga dan lain-lain. ${ }^{2}$

Dengan demikian sudah seharusnya gereja perlu menyadari dan memikirkan bagaimana caranya gereja dapat memenuhi kebutuhan anggotanya dalam hal ini salah satunya anak-anak sekolah minggu. Sekolah minggu adalah sarana penginjilan yang terbesar bagi dunia. Maka sebagai sebuah sarana penginjilan terbesar bagi gereja, guruguru sekolah minggu memegang peranan yang besar dalam proses belajar mengajar. Memang tidak dapat dipungkiri bahwa saat ini pelayanan guru sekolah minggu sedang diperhadapkan dengan tantangan yang sangat kompleks. Tidak sedikit guru-guru sekolah minggu mengeluh karena mengalami krisis murid Sekolah Minggu yang sekian lama mereka asuh. Disatu sisi acara Sekolah Minggu pun harus bersaing keras dengan dunia hiburan anak-anak masa kini, baik yang ditayangkan melalui TV maupun lewat berbagai media yang tersedia dengan para tokohnya yang sangat memikat hati anak-anak.

Pelayanan anak adalah suatu tugas dan tanggung jawab dari Allah. Tugas ini merupakan suatu pekerjaan yang mulia yang dikaruniakan Allah kepada umat-Nya yang terpanggil dalam pelayanan anak. Menjadi seorang pelayan anak bukanlah hal mudah untuk dilakukan. Pelayanan anak membutuhkan hati yang serius dan berkomitmen. Tujuan pelayanan anak adalah membawa anak kepada pengenalan akan Yesus dan menerima Yesus sebagai Tuhan dan Juruselamat serta menolong mereka memiliki hubungan dengan

\footnotetext{
${ }^{1}$ Fredy Simanjuntak, Eko Prasetyo, and Rita Evimalinda, "Praksis Yesus Menafsir Ulang Torah," DIEGESIS: Jurnal Teologi Kharismatika 2, no. 2 (2019): 53-59.

${ }^{2}$ George Barna, Memasarkan Gereja (Bandung: Kalam Hidup, 1988). 18
} 
Tuhan agar mereka bertumbuh dewasa secara Rohani. Harapan ini sepenuhnya belum tercapai karena gereja lebih mengutamakan orang dewasa dari pada pelayanan anak. Sebagaimana Sudi Aryanto mangatakan bahwa "sering gereja menganggap pelayana dewasa itu sangat penting." Artinya bahwa pelayanan orang dewasa teramat sangat penting dari pada pelayanan bagi anak-anak.

Hal ini terlihat jelas bahwa di dalam pelayanan gereja orang dewasa sering mengadakan kegiata-kegiatan kerohanian seperti KKR, kegiatan Kemah Pemuda dan kegiatan lainnya yang memakai fasilitas mewah dan membutuhkan biaya yang cukup banyak. Sedangkan dalam pelayanan anak, gereja tidak terlalu memperhatikan kebutuhan kerohanian anak dengan mengadakan kegiatan-kegitan seperti kegiatan layaknya orang dewasa walau pun ada pasti sangat jarang. Selain itu anak-anak juga sering terabaikan pada waktu anak di layani digereja. Kepribadian anak dalam Alkitab dikatakan bahwa sejak anak dalam kandungan ibunya ia telah berdosa.

Oleh sebab itu orangtua, guru dan pelayan Tuhan perlu memperhatikan dengan seksama bagaimana kepribadian anak-anak dalam kehidupan sehari-hari. Salomo mengatakan di dalam Amsal 22:6 bahwa "Anak yang diajarkan jalan Tuhan, masa tuanya ia tidak menyimpang dari jalan itu". Laufren berkata bahwa: "Dalam masa kanak-kanak terbentuk dasar yang menopang seluruh kehidupan seseorang, konsep-konsep yang dibentuk pada masa ini mempengaruhi masa dewasa mereka. meskipun konsep-konsep itu masih dapat berubah dalam proses perkembangan, namun arah pandang arah pandangan mengenai hidup sudah tertaman, baik positif maupun negatif. ${ }^{3}$ Melalui pernyataan ini dapat diketahui bahwa lingkungan akan terus mempengaruhi kehidupan seorang anak sesuai dengan perkembangan dan kemajuan zaman. Namun sekalipun konsep-konsep yang diajarkan dapat berubah oleh lingkungan, akan tetapi jika pemahaman yang benar sudah ditanamkan sejak anak-anak dan di usia yang masih kecil maka tidak akan mudah terpengaruh oleh lingkungan atau situasi dimana anak tersebut berada.

Dalam kalimat sebelumnya penulis telah mengatakan bahwa pelayanan anak sering diabaikan atau tidak di prioritaskan. Hal ini dapat terlihat dalam pelayanan di gereja, dan merupakan suatu kenyataan yang terjadi saat-saat ini seperti dalam contoh kasus pelayanan anak dibawah ini, yaitu: "Apabila tempat kebaktian anak dekat dengan kebaktian orang dewasa maka anak-anak tidak dibiarkan memuji Tuhan dengan suara keras (yang menunjukan kebebasan untuk memuji Tuhan) karena akan mengganggu kebaktian orang dewasa. Namun apakah pernah terpikir bahwa puji-pujian dari kebaktian orang dewasa begitu keras bisa menggangu anak-anak untuk belajar firman Tuhan. ${ }^{4}$

\section{METODE}

\footnotetext{
${ }^{3}$ Ruth Laufer and Anni Dyrk, Pedoman Pelayanan Anak (Malang: Bahtera Grafira, 1997).23

${ }^{4}$ Sudi Ariyanto, Menciptakan Sekolah Minggu Yang Menyenangkan (Surabaya: Gloria Graffa, 2005).39
} 
Metode yang digunakan dalam penelitian ini adalah metode kualitatif deskriptif dengan pendekatan literatur dan obeservasi, dimana pengertian konsep dasar pelayanan anak menurut matius 19:13-15 dan implementasinya terhadap kualitas pelayanan guru serta pertumbuhan rohani anak sekolah minggu di gbi house of glory batam dideskripsikan secara biblikal sebagai variabel dalam penelitian ini, lalu dikaitkan dengan mempertimbangkan data literatur yang terkait dalam variabel tersebut serta menganalisisnya sebagai temuan faktual deskriptif.

\section{HASIL DAN PEMBAHASAN}

\section{Eksegese Injil Matius 19:13-15}

Untuk memberikan pemahaman yang lebih dari pelayanan anak yang dilakukan Yesus dalam kitab Injil Matius, penulis berusaha menemukan arti pelayanan anak yang sesungguhnya menurut konsep dari ayat ini dengan mengeksegese beberapa ayat dari cakupan ayat bahasan. Yaitu : Matius 19 :13-15 “ Lalu orang membawa anak-anak kecil kepada Yesus, supaya Ia meletakkan tangan-Nya atas mereka dan mendoakan mereka ; Akan tetapi murid-murid-Nya memarahi orang-orang itu. Tetapi Yesus berkata : Biarkan anak-anak itu, jangan menghalang-halangi mereka datang kepada-Ku; sebab orang-orang seperti itulah yang empunya kerajaan sorga." Lalu Ia meletakkan tangan-Nya atas mereka dan kemudian Ia berangkat dari situ."

\section{Membawa}

Dalam ayat ini kata membawa dalam bahasa Yunani: proshne,cqhsan, Dalam bahasa Inggrisnya: "brought"proshne,cqhsan Kata ini berasal dari kata kerja: To bring to, offer verb indicative aorist pessive $3^{\text {rd }}$ person. Dalam Bahasa Indonesi: Untuk membawakan ke, menawarkan bersifat menandakan kata kerja aorist passive orang ke tiga.Defenisi sementara kata ini adalah kata kerja aoris artinya perbuatan yang dilakukan pada satu titik waktu secara keseluruhan, dan diatesis pasif menunjukkan bahwa subjek tidak terlibat lagi untuk selanjutnya. 4374 prosfe, rw prosphero yang dibacapro-fer'-o, Artinya yang pertama adalah untuk dibawa ke, yaitu mengarah kepada seseorang yang dapat menyembuhkannya atau siap untuk menunjukkan kepadanya beberapa kebaikan, satu kepada seseorang yang akan menghakimi dia dan mengarah kepada kata kerja yaitu membawa hadiah atau benda, untuk meraih atau menyerahkan sesuatu untuk diberikan kepada seseorang untuk bertanggung jawab terhadap benda tersebut.

Dalam buku tafsir menyatakan bahwa anak-anak kecil dibawa kepada Yesus; Lukas 18:15 dipakai suatu kata Yunani, yang berarti bayi-bayi atau anak-anak yang masih muda sekali. Dalam bahasa Yunani dapat dilihat bahwa bukan ibu-ibu saja yang membawa anakanak itu; Mungkin bapak-bapak dan ibu-ibu. Maksud mereka adalah supaya Yesus meletakkan tangan-Nya atas mereka dan mendoakannya. Para rabi Yahudi kadang-kadang diminta supaya melakukan hal yang sama juga. 


\section{Memarahi}

Dalam ayat ke 13 Bahasa Yunani: evpeti, mhsan. yang dibaca evpeti, mhsan Dalam bahasa Inggrisnya: rebuked evpeti,mhsan. Kata ini berasal dari susunan kata kerja: To rebuke, warn verb indicative aorist active $3^{\text {rd }}$ person plural. Dalam bahasa Indonesia "Untuk tegur, memperingatkan bersifat menandakan kata kerja aorist aktif orang ke tiga jamak.

Defenisi sementara kata ini adalah kata kerja aoris artinya perbuatan yang dilakukan pada satu titik atau waktu secara keseluruhan, dan diatesis aktif artinya bahwa subjek melakukan tindakan. Setelah ayat-ayat penting di uraikan maka penulis menemukan arti dari ayat 13 yaitu : Tuhan Yesus memberi pendapat-Nya tentang anak-anak bahwa Ia merindukan agar anak-anak mengenal Dia melalui tuntunan dan dukungan orang dewasa. Selanjutnya kata kerja dalam bahasa Yunaninya proshne,cqhsan yang diartikan " untuk membawa dan menawarkan", merupakan kata kerja aorist passive orang ke tiga. Yang berarti subjek tidak terlibat lagi untuk selanjutnya, tetapi yang melanjutkan untuk melayani anak adalah kehendakTuhan.

Kata kerja dalam bahasa Yunani evpeti,mhsanjuga dapat diartikan adalah " untuk tegur, memperingatkan" bersifat menandakan kata kerja aorist aktif orang ke-3 jamak. Yang berarti Yesus menegur murid-murid-Nya agar jangan menghalang-halangi anak-anak datang kepada-Nya, tetapi sampai sekarang perintah Yesus itu tetap berlaku.

Dari uraian pemaparan kata sebelumnya buku tafsir menyatakan bahwa "kita tidak tahu apa sebabnya murid-murid Yesus memarahi orang yang membawa anak itu. Ada bermacam dugaan bagi para penafsir. Barangkali waktu itu Yesus sibuk bercakap-cakap dengan orang-orang dewasa atau Yesus sedang lelah. Bisa juga bahwa murid-murid mengira bahwa Yesus hanya mau berurusn dengan orang dewasa; Mungkin mereka ingat bahwa Yohanes pembaptis, pelopor Kristus, hanya memanggil orang dewasa kepeda pertob

\section{Biarkanlah}

Dalam Bahasa Yunaninya 863 avfi, hmi aphiemiavfi, hmi aphiemi dibacaaf-ee'-aymee. Dalam bahasa Inggrisnya LetKata ini berasal dari susunan kata kerja to let go, permit, forgive verb imperative aorist active 2nd person plural Dalam Bahasa Indonesia untuk lepaskan, permisi, memaafkan sangat mendesak kata kerja orang ke-2 aktif aorist jamak. Defenisi sementara kata ini adalah kata kerja aoris artinya perbuatan yang dilakukan pada satu titik waktu secara keseluruhan, dan diatesis aktif artinya bahwa subjek melakukan tindakan. Artinya: untuk mengirim dan mengajukan tawaran pergi untuk mengirim, menyerahkan, melepaskan, apalagi, membiarkan menjadi, mengabaikan untuk pergi, bukan untuk membahas sekarang, untuk mengizinkan, tidak menghalangi, untuk menyerahkan sesuatu kepada seseorang untuk pergi, tinggalkan dia untuk dirinya sendiri sehingga semua klaim bersama ditinggalkan. 
Buku tafsir berkata bahwa tidaklah penting apa gerangan alasan kelakuan muridmurid Yesus. Penting saja kelakuan Yesus sendiri terhadap anak-anak itu. Ia menyambutnya dan memberkatinya. Bahkan di Markus 10:16 di katakana bahwa Ia memeluk mereka.

Menurut buku Injil sinoptis berkata bahwa" kata biarkan anak-anak itu" Dalamterjemahan bahasa Inggris digunakan arti " jangan menyakiti atau merugikan. Anakanak itu tidak memerlukan apa-apa selain kasih sayang Yesus.”

\section{Menghalang-halangi}

Dalam Bahasa Yunaninya kwlu, w koluo kwlu, w koluo dibaca ko-loo'-o. Artinya: untuk menghalangi, mencegah melarang, untuk menahan sesuatu dari siapa pun, untuk menyangkal atau menolak satu hal. Dalam Bahasa Inggris: do not prevent kwlu,ete kata kerja ini berasal dari susunan kata kerja to forbid, hinder, prevent verb imperative present active $2^{\text {nd }}$ person. Dalam bahasa Indonesia untuk larang, rintangi, cegah hadiah sangat mendesak kata kerja aktif orang kedua. Defenisi sementara kata ini adalah kata kerja diatesis aktif menekankan bahwa subjek melakukan tindakan.

Buku Injil sinoptis nerkata bahwa; "murid-murid belum mengalami pandangan tentang hidup dikerajaan sorga yang akan terbentuk tidak lama lagi. Mereka hanya melihat kesibukan pelayanan Yesus pada saat ini, yaitu mengajar dan menyembuhkan orang sakit. Sehingga kedatangan anak-anak kecil dianggap dapat menghalangi pelayanan Yesus." Menghalangi anak datang kepada Yesus lebih-lebih merupakan tindakan yang salah, salah satu contoh orangtua yang melarang anak untuk pergi ke gereja atau ke Sekolah Minggu dengan alasan takut pelajaran sekolah anak terhalangi dan sebagainya.

\section{Empunya Kerajaan Sorga}

Dalam Bahasa Yunani evsti.n, evsti.n dibaca eivmi, (eimi) kata kerja indikatif hadir aktif orang ketiga tunggal dari eivmi, Dalam bahasa Inggris belongs, Artinya: Saya ada, saya ada, Penggunaannyadisertai, menemani, saya menegaskan, menjadi, telah, milik, termasuk, membawa, telah terjadi hidup, berarti, berasal, memiliki, tetap. Kata Kerajaan Sorga dalam bahasa Yunani adalah basileia basileia dibaca bas-il-i'-ah. Kata ini berasal susunan dari kata benda ini adalah The defenitif article nominative feminine singular. Dalam bahasa Indonesia "Artinya adalah satu nominatif kata benda Kerajaan bentuk tunggal feminin". Defenisi sementara kata ini adalah kata benda akusatif tunggal. Basilei, Artinya: kekuasaan kerajaan, kekuasaan raja, kekuasaan, kekuasaan tidak dikacaukan dengan kerajaan yang sebenarnya, tetapi hak atau wewenang untuk memerintah kerajaan dari kekuasaan kerajaan Yesus sebagai Mesias yang menang dari kerajaan kekuasaan dan martabat yang diberikan kepada orang-orang Kristen di kerajaan Mesias sebuah kerajaan, wilayah yang tunduk pada pemerintahan seorang raja yang digunakan dalam Perjanjian Baru untuk merujuk pada pemerintahan Mesias. 
Buku Injil Sinoptis mengatakan bahwa "Terjemahan dalam bahasa Indonesia tentang "orang-orang seperti itulah yang empunya kerajaan sorga" menimbulkan pertanyaan tentang pemilikan kerajaan sorga. Dalam terjemahan bahasa Inggris disebutkan "kerajaan sorga adalah seperti demikian; Kasih anak-anak kecil kepada Tuhan itulah yang harus meliputi hidup persekutuanantara tubuh Kistus dengan kepala yakni Kristus.

Setelah Ayat 14 diuraikan sesuai kata yang penting maka arti ayat ini adalah sebagai berikut; kata ini diawali dengan kata "tetapi" artinya adalah "Tidak selaras, meskipun dan namun." Kata ini adalah penghubung dari ayat 13 "Dimana tindakan murid-murid-Nya berbeda dengan konsep Yesus tentang anak-anak. Dilanjutkan dengan kata kerja bahasa Yunani yang artinya adalah " untuk larang, rintangi, cegah hadiah sangat mendesak". Adalah kata kerja aktif orang ke-2. Berarti sikap Yesus adalah memarahi murid-murid-Nya.

Dari uraian ayat 14 ini, maka penulis menemukan arti bahwa Yesus merindukan peayanan anak sangat penting dan harus lebih diprioritaskan. Buku tafsiran berkata bahwa "Hati Yesus tak pernah berubah dan sekarang ini hati Yesus yang sudah bagkit, yang hidp dan yang menyertai gereja pastilah masih terbuku untuk ana-anak sama seperti pada waktu itu" orang-orang yang seperti itu (artinya sama seperti anak-anak itu) yang empunyai kerajaan sorga.

\section{Konsep Teologis Pelayanan Anak Menurut Matius 19:13-15}

Perkataan Yesus tentang pelayanan anak yang di ucapkan dalam Injil Matius 19:13-15 ada tambahannya adalam Injil Markus dan Lukas. Ketika Yesus naik ke surga, Ia memberi mandat kepada seluruh murid untuk pergi keseluruh dunia dan menjadikan semua bangsa muridNya. Mandat ini menjadi tugas dan tanggungjawab setiap orang percaya yang adalah gereja itu sendiri. ${ }^{6}$ Gerejalah yang menjadi utusan Allah yang bertanggungjawab atas iman dan kehidupan Rohani setiap anggota jemaatnya tidak terkecuali anak-anak yang adalah bagian dari jemaat, gereja harus bertanggungjawab sampai suatu hari kelak anakanak ini dapat bertanggungjawab atas iman dan kehidupan Rohani mereka secara mandiri.

Kitab perjanjian Lama juga menyebutkan tentang pentingnya pelayanan kepada anak-anak tersebut. Amsal 22:6 menyebutkan "Didiklah orang muda menurut jalan yang patut baginya, maka pada masa tuanya pun ia tidak menyimpang dari jalan itu". Amsal adalah kitab yang masuk dalam kumpulan hikmat, kumpulan sastra yang mewakili hikmat tradisional. Pendidikan dan dan pengajaran yang ada dalam kitab Amsal ini umumnya di tujukan kepada anak-anak generasi muda. ${ }^{7}$ Secara khusus juga melaksanakan perintah dan sikap Tuhan Yesus kepada anak-anak seperti yang terhadap dalam Matius 19:13-15 "Lalu orang membawa anak-anak kecil kepada Yesus, supaya Ia meletakkan tangan-Nya atas

\footnotetext{
${ }^{5}$ Hasan Alwi, Kamus Besar Bahasa Indonesia (Jakarta: Balai Pustaka, 2005). 756

${ }^{6}$ Paulus Darm, Pengantar Ke Dalam Sekolah Minggu (Jakarta: BPK Gunung Mulia, 1989).3

${ }^{7}$ S. Wismoady Wahono, Disini Kutemukan (Jakarta: BPK Gunung Mulia, 2004).223
} 
mereka dan mendoakan mereka, akan tetapi murid-muridNya memarahi orang-orang itu. Tetapi Yesus berkata: 'Biarkanlah anak-anak itu, janganlah menghalang-halangi mereka datang kepad-Ku, sebab orang-orang yang seperti itulah yang empunya kerajaan sorga."

\section{Tuhan Menghendaki Anak-Anak Dibawa Kepada-Nya}

Dari peristiwa pelayanan yang dilakukan Yesus menurut Matius 19:13-15 menjelaskan betapa Tuhan Yesus sangat mengasihi anak-anak dan menghendakii mereka untuk datang kepada-Nya. Dan Tuhan Yesus memerintahkan agar jangan seorang pun menghalangi anak-anak melainkan supaya orang dewasa membawa anak-anak datang kepada-Nya. Tuhan Yesus sangat memperhatikan keadaan anak-anak " Ia rindu untuk menerima, mengasihi dan memberkati mereka." Bukan hanya itu, tetapi Tuhan Yesus "Sangat memperhatikan keselamatan dan pembinaan rohani anak-anak." Oleh sebab mereka adalah jiwa yang membutuhkan keselamatan yang disediahkan bagi semua umat manusia yang percaya.

\section{Dari Sejak Dini Anak Dibawa Mengenal Tuhan}

Dalam bab sebelumnya penulis mengatakan bahwa pelayanan anak sangat penting, untuk orang dewasa harus menolong dan menuntun anak-anak untuk datang kepada Yesus.

Samuel adalah seorang contoh tokoh anak yang dari sejak dini telah diserahkan kepada Tuhan. Samuel adalah anak dari Elkana, ibunya adalah Hana. Sejak dari dalam kandungan, Samuel dijanjikan Hana supaya menjadi pelayan di Bait Allah. Gien Karssen berkata; "Segera sesudah Samuel disapih, Hana menepati janji dan memberikan dia kembali kepada Allah yang telah mengaruniakan anak itu kepadanya. ${ }^{8}$

Dari pemaparan diatas Hana adalah seorang ibu yang takut akan Tuhan yang mengetahui tujuan hidupnya bahwa ia akan menjadikan Samuel anaknya, seorang pahlawan bagi bangsanya. Dilanjutkan lagi oleh Gien Karssen yang mengungkapkan bahwa; "Allah menyatakan diri-Nya melalui Samuel sejak Samuel masih kecil. Dari dan sampai ke Utara, yaitu ke Bersyeba dan jauh ke Selatan, orang-orang tahu bahwa Samuel adalah nabi yang ditetapkan Allah." Dari kehidupan Samuel ini, penulis menyimpulkan bahwa anak sangat membutuhkan orang dewasa seperti yang dilakukan Hana kepada anaknya dengan membawa Samuel kepada Yesus. Sebab anak adalah bagian terpenting dari tubuh Kristus. Seperti yang telah diungkapkan oleh Stormie berkata bahwa "Setiap orang yang percaya kepada Yesus disebut tubuh Kristus. Sebab mereka juga adalah bagian dari kerajaan sorga mereka sangat penting." Jadi, sebagai satu tubuh dalam Kristus maka anak diperlukan untuk saling melengkapi antara anak-anak dengan orang dewasa.

\section{Anak Didoakan}

\footnotetext{
${ }^{8}$ Gien Karssen, Ia Dinamai Perempuan (Bandung: Yayasan Kalam Hidup, 2008).111
} 
Anak membutuhkan doa, baik anak yang masih ada dalam kandungan ibunya maupun anak yang sudah lahir. Sebab anak yang masih dalam kandungan adalah bakal jiwa yang memiliki roh untuk menangkap rangsangan dari lingkungan luar. Anak yang di doakan dan diserahkan kepada Tuhan dari sejak dalam kandungan ibunya sampai ia lahir apabila anak itu besar akan menjadi anak takut akan Tuhan. Dapat dilihat dari beberapa tokah Alkitab, seperti: Samuel, Simson dan Tuhan Yesus. Jadi, "Sebenarnya adalah ide yang bagus untuk memulai berdoa lagi bagi anak-anak sebelum mereka lahir."9

Tuhan Yesus melakukan pelayanan anak dengan mendoakan anak-anak yang datang kepada-Nya (Markus 10:16). Artinya bahwa anak-anak berlu didoakan. A.B. Susanto berkata bahwa: “ Anak didoakan agar tidak hanya meminta tetapi juga memelihara dan memberi makna. ${ }^{10} \mathrm{Jadi}$, doa mampu menjadikan anak melakukan sesuatu atau memberi makna dalam lingkungannya.

\section{Anak Diberkati}

Tuhan Yesus melakukan pelayanan terhadap anak-anak, Ia meletakkan tanganNya atas anak-anak. Contoh dalam Perjanjian Lama,orangtua yang memberkati anaknya ialah Abraham. Abraham memberi berkat kepada Ishak, Ishak memberi berkat kepada Yakub, lalu Yakub memberi berkatnya kepada Yusuf dan kedua cucunya dari keturunan Yusuf sehingga berkat itu turun temurun sampai sekarang. Artinya bahwa anak perlu di berkati melalui orangtua, para pelayan atau guru Sekolah Minggu, guru di sekolah, serta orang-orang yang ada di gereja.

\section{Anak Dikasihi dan Dirangkul}

Tuhan Yesus melakukan pelayanan anak dengan cara memeluk anak-anak dan mengasihi mereka, peristiwa itu para murid-Nya menghalangi anak-anak datang kepadaNya, lalu Ia memarahi murid-Nya tetapi anak-anak itu dipeluk dan dikasihi (Markus 10:). Artinya bahwa Ia memberikan perhatian yang khusus dan mengerti sifat anak-anak yang sederhana. "Seseorang yang mengasihi anak adalah cukup untuk memampuhkan mereka menanggung ketidaknyawaan dalam mejalankan disiplin, untuk melakukan segala sesuatu didalam kuasanya didalam kuasanya memelihara mereka. ${ }^{11}$ Oleh karena itu peranan orangtua sangat penting untuk memberikan perhatian khusus seperti mengasihi dan merangkul mereka agar mereka merasa nyaman menjalankan yang benar sesuai dengan ajaran Firman Tuhan.

\section{Anak Dibimbing Untuk Beribadah}

\footnotetext{
${ }^{9}$ Quin Sherrer and Ruthanne Garlock, Cara Mendoakan Anak-Anak Anda (Bandung: Yayasan Kalam Hidup, 2002).31

${ }^{10}$ A.B. Susanto, Meneladani Jejak Yesus Sebagai Pemimpin (Yogyakarta: Andi Offset, 2006).185

${ }^{11}$ Straus L Richard, Betapa Senangnya Mengenal Allah (Jakarta Barat: Mimery Press, 1990).14
} 
Penulis telah mengatakan pada memaparan sebelumnya bahwa anak-anak memiliki sifat yang baik yaitu memliki kepercayaan penuh kepada Bapa di sorga. Tuhan Yesus mengatakan jangan menghalangi anak-anak datang kepada-Nya agar nak-anak mengenal Tuhan (Matius 19:13). Artinya bahwa orang dewasa perlu menuntun anak mengenal Tuhan melalui persekutuan kerohanian anak agar iman mereka bertumbuh.

Apabila dilihat dari kepribadian anak, anak memiliki hati penuh percaya kepada Tuhan Yesus. Seperti yang dikatakan oleh Stanley:“Anak tidak segan-segan hidup bersandar kepada Yesus dalam setiap pergumulan dan setiap kegiatannya. Bahakan anak sangat kecewa ketika melihat orangtuanya tidak taat kepada Firman Allah mereka sendiri telah mengetahui kebenaran Firman Tuhan."

Dari penulisan diatas penulis mengartikan bahwa ada tiga pernyataan yang dikutip yaitu: Bahwa anak memiliki hati untuk percaya kepada Tuhan seperti orang dewasa, anak mampu menegerti Firman serta anak membutuhkan keteladanan dari orang dewasa. Dari ketiga pernyataan ini penulis simpulkan bahwa anak-anak membutuhkan persekutuan untuk membangun kerohanian mereka yang sama seperti orang dewasa yang sudah mengerti kebenaran Firman Tuhan.

\section{Anak Dilayani Secara Kreatif}

Anak-anak memiliki keterbatasan untuk berbuat sesuatu yang berarti untuk mengembangkan potensinya tanpa adanya dukungan dari orang dewasa yang akan menolong atau menuntun mereka. dari keterbatasan anak-anak ini maka mereka membutuhkan pelayanan yang kreatif agar mereka mampu menangkap apa yang mereka terima. Seperti yang dilakukan oleh Tuhan Yesus bahwa; Ia mampu mengerti keadaan anak-anak di peluk, diberkati dan didoakan. Melayani anak dengan kreatif akan lebih mudah apabila anak dan palayan memiliki hubungan yang baik.

\section{Keunikan Anak Dihadapan Tuhan}

Anak-anak memiliki keunikan dalam pandangan Allah. Alkitab penuntun berkata bahwa; "Menerima kerajaan Allah seperti seorang anak kecil berrati menerimanya dengan sikap yang polos, rendah hati, penuh keyakinan dan sungguh-sungguh."12 Ketika karakteristik anak ini merupakan keunikan anak dihadapan Tuhan.

\section{Memiliki Kepercayaan Penuh Kepada Allah}

Anak-anak percaya kepada seorang yang mampu memelihara dan memberikan rasa damai atau nyaman dimana mereka berada. Sedangkan orang dewasa berusaha agar berkenan kepada Allah melaului peruatan baik. ${ }^{13}$ Sehingga perbedaan anatara sifat anakanak dengan orang dewasa sangat jelas terlihat.

\footnotetext{
${ }^{12}$ Alkitab Penuntun (Malang: Gandum Mas dan Lembaga Alkitab Indonesia, 2000).1601

${ }^{13}$ Laufer and Dyrk, Pedoman Pelayanan Anak.7
} 
Tuhan Yesus berkata "Sebab orang yang empunya kkerajaan Allah"( Markus 10:15). Nimery dalam bukunya Injil Sinoptis mengartikan bahwa: "Anak-anak tidak memerlukan apa-apa selain kasih sayang Yesus ${ }^{14}$ Jadi anak-anak memiliki keyakinan yang tidak memiliki unsur atau motivasi yang salah. Hal ini di dukung oleh J.J De Heer yang berkata bahwa ;

"Mereka menggantungkan dirinya kepada orangtua dan percaya bahwa orangtua itu akan memeliharanya. Sama seperti seorang yang sungguh Kristen yakni bahwa ia kecil saja, tetapi selalu ingat akan Bapanya yang disorga dan percaya bahwa Bapa yang disorga itu menyediakan keperluan-keperluan rohaninya dan jasmani."

Serta di dukung oleh Richard yang berkata bahwa; " Anak-anak sangat bersedia untuk memberikan segala sesuatau yang dimilikinya kepada seseorang yang mengasihi mereka dan merawat mereka dengan baik, yang menentukan batas tingkah laku mereka dan menegur mereka dengan penuh kasih pada waktu mereka melanggarnya. ${ }^{15}$

\section{Memiliki Hati Yang Tulus}

Hati anak-anak dengan hati orang dewasa sangatlah berbeda. Hati orang dewasa sulit menerima apa yang ada dihadapannya sedangkan hati anak-anak ketika mendengar dan megerti tentang kasih Yesus ia sering kali siap membuka hati. seperti yang diungkapkan oleh Laufer bahwa; "orang dewasa jauh lebih sulit menerima apa yang disediakan oleh Tuhan. ${ }^{16}$ Dan anak-anak kecil mengasihi Tuhan dengan hati yang polos, tidak ada unsur lain dibalik kasih mereka. Itulah sebabnya Allah membuat anak adalah sebagai lambang bagaimana sikap hati untuk datang kepada Yesus Kristus menerima sebagai TUhan dan Juruselamat setiap pribadi manusia.

\section{Memiliki Kerendahan Hati}

Tuhan Yesus berkata bahwa; Barangsiapa yang merendahkan diri dan menjadi seperti anak kecil ini, dialah yang tersebesar dalam Kejaraan Sorga. Ayat ini berbicara bagaimana tentang kaidah Allah yaitu kebesaran, kedudukan dan kekuasaan. Yang dinilai besar oleh Allah adalah mereka yang merendahkan diri dan menjadi seperti anak kecil. Dalam buku tafsir dikatakan bahwa " Anak-anak mengetahui bahwa mereka sanagt kecil saj, mereka menggantungkan dirinya kepada orangtua dan percaya bahwa orangtua itu akan memeliharanya. ${ }^{17}$

Tuhan tidak senang kepada orang yang sombong tetapi Ia senag kepada orang yang rendah hati, ia berkata dalam 1 Petrus 5:5-6 bahwa " Rendahkanlah dirimu seorang terhadap yang lain, sebab: “ Allah menentang orang yang congkak, tetapi mengasihani

${ }^{14}$ William Barclay, Pemahaman Alkitab Setiap Hari, Injil Matius 11-28 (Jakarta: BPK Gunung Mulia, 2017). 144

${ }^{15}$ Richard, Betapa Senangnya Mengenal Allah.14

${ }^{16}$ Laufer and Dyrk, Pedoman Pelayanan Anak.7

${ }^{17}$ J. J. De Heer, Tafsiran Alkitab Injil Matius (Jakarta: BPK Gunung Mulia, 2003).376 
orang yang rendah hati." Karena itu rendahkanlah dirimu di bawah tangan Tuhan yang kuat, supaya kamu di tinggikan-Nya pada waktunya. Sedangkan barang siapa merendahkan diri dan menjadi seperti anak kecil, dialah yang terbesar dalam Kerajaan Sorga" ( Matius 18:14). Dalam Injil Matius 23:12 di katakan bahwa "Barangsiapa meninggikan diri, ia akan direndakan dan barangsiapa merendahkan diri, ia akan ditinggikan." Dari ayat ini menunjukan bahwa Allah merindukan setiap orang yang percaya harus memiliki sikap hati seperti anak-anak yaitu memiliki kerendahan hati.

\section{Peranan Pelayanan Anak Sekolah Minggu}

Penulis telah mengatakan bahwa landasan pelayanan anak adalah Alkitab. Pelayanan anak bukanlah pelayanan yang baru muncul, namun pelayanan anak telah ada sejak zaman Perjanjian Lama. Pelayanan bagi anak-anak telah diperintahkan Allah kepada Musa untuk disampaikan kepada bangsa Israel. Karena itu dalam Perjanjian Lama maupun Perjanjian Baru pelayanan anak telah ada hingga sekarang.

Pelayanan anak sangat penting untuk dilakukan. Melayani anak adalah kehendak Allah. Allah menginginkan agar anak mengenal Dia. Namun pengalaman yang benar tentang pelayanan anak tidak semua orang dewasa mengetahuinya. Karena itu pelayanan anak yang benar dalam gereja perlu diketahui kebenaran yang sesungguhnya sesuai Firman Tuhan.

Pelayanan anak digereja, keluarga maupun disekolah merupakan suatu cara yang efektif mengajar anak maka anak menjadi pribadi yang bermoral dan rohani serta melakukan kehendak Allah. Tujuan pelayanan terhadap anak agar mereka memiliki kekuatan Roh dan Firman Tuhan yang lebih pada waktu mereka dewasa. Pendidikan Non Formal Agama Kristen adalah pendidikan dalam keluarga dan pendidikan Sekolah Minggu dengan peserta dari usia bayi sampai usia dua belas tahun. ${ }^{18}$

\section{Membawa Anak Datang Kepada Yesus}

Yesus mengatakan bahwa "Biarkanlah anak-anak itu jangan menghalang-halangi mereka datang kepada-Ku sebab orang yang seperti itulah yang empunyai kerajaan sorga" ( Matius 19:14). Buku tafsir oleh Nomery berkata bahwa: "kata "Biarkan" Dalam terjemahan bahasa inggris digunakan kata jangan menghalang-halangi artinya "jangan menyakiti atau merugikan"19 Artinya bahwa orang dewasa jangan mebuat anak-anak tidak mengenal Tuhan Yesus, tetapi sebaliknya orang dewasa harus menolong ataupun menuntun mereka untuk datang kepada-Nya sebab Tuhan Yesus mengasihi anak-anak.

\section{Mempersiapkan Anak Agar Bertumbuh Dalam Takut Akan Tuhan}

\footnotetext{
${ }^{18}$ Ayub Yahya, Menjadi Guru Sekolah Minggu Yang Efektif (Yogyakarta: Footprints Publishing, 2011).21

${ }^{19}$ Barclay, Pemahaman Alkitab Setiap Hari, Injil Matius 11-28.114
} 
Peranan atau tanggungjawab orang dewasa maupun gereja terhadap pelayanan anak adalah mempersiapkan anak agar imannya bertumbuh dalam takut akan Tuhan. Untuk mempercayai hal ini maka diperlukan tindakan yang berasal dari kesadaran hati dan di perukan persiapan waktu.

Memperkenalkan anak menjadi seseorang yang mengasihi Tuhan diperlukan persiapan yang memerlukan jenjang waktu yang cukup lama bahkan sampai seumur hidup. Sebab Allah mempunyai rencana bagi tiap pribadi anak, karena itu tiap-tiap anak harus mempunyai hubungan dengan Tuhan, taat pada tuntunan Roh Kudus, menjadi orang yang ditentukan oleh Allah menurut rencana-Nya. Dan mau mempersembahkan tubuhnya serta memuliakan Tuhan dalam setiap langkah hidup.

\section{Memenuhi Kebutuhan Rohani Anak}

Anak membutuhkan agar kerohaniannya disegarkan, dengan melakukan persekutuan atau ibadah anak-anak. Diatas penulis telah membagi kebutuhan anak ada tiga, salah satunya adalah kenutuhan Rohani. Kebutuhan Rohani ialah seperti kebutuhan kasih sayang, disiplin, perlakuan sebagai seorang individu, kesempatan untuk bertumbuh dan keamanan rohani secara langsung.

Menurut Alfred Adler berkata bahwa; Ada tiga tujuan yang mendasari perilaku seseorang yaitu kebutuhan untuk memiliki, untuk diterima, untuk berkontribusi. Dari ketiga kebutuhan ini membuat seseorang merasa terpuaskan, apabila kebutuhan manusia tidak terpenuhi maka ia akan mencarinya tetapi apabila kebutuhannya terpenuhi maka akan merasakan kepuasan hidup. Jadi kebutuhan anak perlu dipenuhi agar ia mampu mengekspresikan dengan maksimal segala kemampuan yang mereka miliki.

\section{Tujuan Pelayanan Anak Yang dimaksud Yesus}

Dalam Alkitab ada banyak tokoh-tokoh yang berhasil menjadi pemimpin bangsa, ketika dipanggil dan dipersiapkan Tuhan sejak mereka masih anak-anak. Contohnya adalah Yusuf, Samuel, Daud, dan Tuhan Yesus, serta banyak hamba-hamba Tuhan besar dipersiapkan Tuhan sejak anak-anak. Peranan gereja sebagai ladang mempersiapkan caloncalon generasi yang akan berhasil dimasa yang akan datang maka gereja yang bertumbuh adalah gereja yang memperhatikan pembinaan rohani anak-anak, menjadikan iman anak bertumbuh dewasa sebab anak-anak adalah regenerasi gereja. Sesungguhnya pelayanan anak merupakan ladang yang sangat subur untuk memenangkan jiwa. Memenangkan seseorang semasa kanak-kanak berarti memenangkan seluruh kehidupannya. Pendeta Dwight L. Moody, seorang hamba Tuhan yang terkenal dalam pelayanan penginjilan pernah menyatakan. Bahwa; "Apabila ia memenangkan jiwa seorang yang sudah lanjut usia, ia memenangkan sisa umur hidupnya, tetapi apabila ia memenangkan jiwa seorang anak muda berarti ia memenangkan seluruh kehidupannya." Dari pernyataan diatas penulis mengartikan bahwa hal ini menjadi suatu pemahaman yang perlu diketahui oleh oang 
dewasa bahwa masa anak-anak adalah masa yang mulai bertumbuh seperti tunas pohon, apabila ia dirawat maka pohon itu akan menghasilkan buah yang sangat banyak dan baik tetapi apabila pohon itu tidak dirawat maka tidak akan menghasilkan apa-apa.

\section{Memberi Pengertian Kepada Gereja}

Pelayanan anak yang sangat di rindukan Tuhan Yesus adalah pelayanan anak yang serius serta memprioritaskannya. Dengan begitu Gereja harus menanamkan sesuatu yang ilahi dihati anak yang tidak bisa dicabut oleh lingkungan mereka yang mencoba mempengaruhi mereka menjadi anak yang nakal. Seperti yang dikatakan oleh Stanly, bahwa; "Dari masa kanak-kanak harus ditanam nilai-nilai kejujuran, nilai pengampunan, nilai mengasihi, nilai kesetiaan kepada Tuhan. Pada akhirnya gereja akan melahirkan generasi masa depan gereja dan bangsa yang mmeberi dampak bagi masyarakat.”

Pelayanan anak berperan penting dalam pertumbuhan gereja. Apabila dilihat dari karakteristik anak seperti yang penulis jelaskan diatas, maka anak-anak mempunyai kesanggupan untuk menjadi pemberita Injil yang baik. Mereka dengan senang hati dan penuh sukacita akan mengajak teman-teman dan saudara bahkan orangtuanya untuk mengikuti Tuhan Yesus.

\section{Memberi Kesadaran Kepada Orang Dewasa}

Menghargai bakat anak-anak untuk berkreativitas, serta tidak meremehkan potensi yang ada pada anak-anak sehubungan dengan perintah Yesus ini, maka dibutuhkan pelayan-pelayan anak yang serius dalam bidang ini. "Salah satu prioritas utama bagi orang percaya adalah memberi teladan lewat cara hidup dan ajaran bagi anka-anaknya."20 "Memang sangat sangat baik bila seorang memiliki beban yang sangat besar untuk pelayanan, terlebih pelayanan anak. Akan tetapi, para guru harus diperlengkapi diri dengan keterampilan atau pengetahuan agar dapat menyampaikan berita sukacita kepada anak-anak lebih lagi. $^{21}$

\section{KESIMPULAN}

Kualifikasi rohani merupakan hal yang sangat penting yang harus dimiliki oleh seorang pelayanan sekolah minggu. Oleh karena itu, Pelayanan sekolah minggu merupakan pelayanan yang memiliki tanggung jawab yang besar, akan tetapi Allah juga memberi penghargaan besar. Di atas bahu guru sekolah minggu inilah tergantung masa depan generasi penerus gereja Tuhan. Jika seorang guru sekolah minggu menyerahkan hatinya kepada Tuhan maka Tuhan akan. Seorang guru sekolah minggu haruslah seorang yang sudah lahir baru, yang rohnya telah di baharui oleh Roh kudus. Guru memiliki kewajiban untuk memperkenalkan Kristus kepada anak-anak. Hal ini hanya akan mungkin bila guru

\footnotetext{
${ }^{20}$ Alkitab Penuntun. 1601

${ }^{21}$ Ariyanto, Menciptakan Sekolah Minggu Yang Menyenangkan.42
} 
telah mengenal Allah dan hidup sesuai dengan kebenaran Firman Allah. Pentingnya mengenalkan anak-anak kepada Allah menjadi tanggungjawab dan tantangan bagi setiap orangtua. Anak adalah anugerah dari Allah bagi setiap orangtua dan orangtua harus mendidik mereka sesuai dengn kebenaran Firman Tuhan sehingga anak-anak memiliki bekal hidup yang kekal untuk menjalani hari-hari mereka dikemudian hari.

\section{KEPUSTAKAAN}

Alwi, Hasan. Kamus Besar Bahasa Indonesia. Jakarta: Balai Pustaka, 2005.

Ariyanto, Sudi. Menciptakan Sekolah Minggu Yang Menyenangkan. Surabaya: Gloria Graffa, 2005.

Barclay, William. Pemahaman Alkitab Setiap Hari, Injil Matius 11-28. Jakarta: BPK Gunung Mulia, 2017.

Barna, George. Memasarkan Gereja. Bandung: Kalam Hidup, 1988.

Darm, Paulus. Pengantar Ke Dalam Sekolah Minggu. Jakarta: BPK Gunung Mulia, 1989.

Heer, J. J. De. Tafsiran Alkitab Injil Matius. Jakarta: BPK Gunung Mulia, 2003.

Karssen, Gien. Ia Dinamai Perempuan. Bandung: Yayasan Kalam Hidup, 2008.

Laufer, Ruth, and Anni Dyrk. Pedoman Pelayanan Anak. Malang: Bahtera Grafira, 1997.

Richard, Straus L. Betapa Senangnya Mengenal Allah. Jakarta Barat: Mimery Press, 1990.

Sherrer, Quin, and Ruthanne Garlock. Cara Mendoakan Anak-Anak Anda. Bandung:

Yayasan Kalam Hidup, 2002.

Simanjuntak, Fredy, Eko Prasetyo, and Rita Evimalinda. "Praksis Yesus Menafsir Ulang

Torah.” DIEGESIS: Jurnal Teologi Kharismatika 2, no. 2 (2019): 53-59.

Susanto, A.B. Meneladani Jejak Yesus Sebagai Pemimpin. Yogyakarta: Andi Offset, 2006.

Wahono, S. Wismoady. Disini Kutemukan. Jakarta: BPK Gunung Mulia, 2004.

Yahya, Ayub. Menjadi Guru Sekolah Minggu Yang Efektif. Yogyakarta: Footprints Publishing, 2011.

Alkitab Penuntun. Malang: Gandum Mas dan Lembaga Alkitab Indonesia, 2000. 